\title{
Understanding service recovery satisfaction from a service encounter perspective: A pilot study
}

\author{
C. Boshoff* \\ Department of Business Management, University of Stellenbosch, \\ Stellenbosch, 7600, Republic of South Africa \\ cboshoff@sun.ac.za
}

Received March 2007

\begin{abstract}
When a service provider fails to meet the expectations of customers during a so-called service encounter, the resultant disconfirmation can lead to a series of negative outcomes such as defection and negative word-of-mouth. Often, however, errant firms are afforded a second opportunity by complaining customers to rectify their misdemeanours - a practice referred to as service recovery. Service marketers' understanding of service recovery is, however, limited. This study investigates service recovery from a service encounter perspective by considering the influence of what the complaining customer can visually see during the encounter. The underlying premise of the study is that, during the service encounter the complaining customer is exposed to stimuli such as the physical features and appearance of the service provider and these features can influence their assessment of the service firm's efforts to resolve their complaint.
\end{abstract}

By drawing on social psychology theory this study investigates whether what a complaining customer sees during the service encounter (what the service provider looks like) influences their satisfaction with the service recovery efforts of the firm. The empirical results of this pilot study do not support the general contention of the social psychology theories investigated in this study.

*To whom all correspondence should be addressed.

\section{Introduction}

It is estimated that services contribute as much as two-thirds of South Africa's Gross Domestic Product (World Bank, 2006), and in most Westernised countries it is even more. The growth of the service sectors of most economies of the world has lead to the development of a relatively new subdiscipline in marketing - the marketing of services. The growing importance of services, characterised by intangibility, inseparability, heterogeneity and perishability, has posed new challenges to marketers. Unlike the marketing of goods, services marketing involves attempting to market intangible market offerings, abstract ideas and processes to consumers. As services may or may not include physical attributes, problems were encountered when marketers attempted to use conventional 'product marketing' principles, techniques and tactics which spawned the new sub-discipline of 'service marketing'.

As the realisation dawned that the concept 'services' is unique from a marketing perspective, service marketers and researchers investigated many customer-related aspects of services, including the so-called 'service encounter' and the resulting customer satisfaction. The 'service encounter' refers to the period during which a service provider (such as a bank clerk) and a service buyer interact in a face-to-face situation. The exploration of the concept 'service encounter' has led to the conclusion that customer service satisfaction is based on a post-encounter comparison between customer perceptions of actual service received and (pre-encounter) expectations. In order to realise customer service satisfaction, service marketers must be able to close this perceptual gap between customers' pre-encounter expectations and their assessment of actual service performance to enhance service quality perceptions.

Unfortunately service firms do not always succeed in satisfying customer needs. The disconfirmation that occurs during a service failure leads to a variety of 'negative' consumer behaviours, including the lodging of complaints. How service firms respond to these situations is referred to as 'service recovery'.

\section{Service recovery}

Owing to the human nature of service delivery, the occurrence of some service failures is almost inevitable. Persistently poor service delivery will, however, have a harmful impact on the survival and growth prospects of service firms. 'Service recovery' refers to the actions by a service firm to restore a customer to a state of satisfaction after a service failure. In other words, service recovery offers the firm a second opportunity to meet a service customer's expectations. Service recovery is of particular importance to service firms. Poor or ineffective service recovery leads to undesirable outcomes such as customer complaints, defections to competing firms and negative word-of-mouth. Effective service recovery (satisfaction with service recovery), on the other hand, avoids these negative outcomes and may even strengthen customer loyalty. 
Customer perceptions of service delivery have been shown to be influenced by the environment in which service delivery takes place (Bitner, 1990) and service recovery is no exception.

\section{The servicescape}

The recognition of the importance of situational variables (a point in time and space) in consumer decision-making is beyond dispute. Consumer behaviourists such as Engel, Kollat and Blackwell (1969) called for the incorporation of both individual and situational variables in consumer decision-making studies almost 40 years ago. Belk (1975) refers to the 'environment' as a concept that includes time, place, and behavioural dimensions.

Research conducted by service marketing researchers such as Prasuraman, Zeithaml and Berry (1988) and Bitner (1990) have highlighted the importance of the physical service environment on customer satisfaction (referred to by the former as 'tangibles'). Bitner (1990) coined the phrase 'servicescape' to describe the environment in which service delivery/the service encounter takes place. Based on stimulus-organism-response theory, Zeithaml, Bitner and Gremler (2006: 329) conclude that a customer enters a service environment for a service encounter that can either be enhanced or be constrained by the environment. Based on stimulus-organism-response theory, managers are thus urged to create an environment/servicescape that will enhance the customer's experience and thus post-encounter perceptions such as service quality evaluations and satisfaction.

In addition, both social identity theory and similarityattraction theory suggest that what consumers visually see during a service encounter will impact on their perceptions and subsequent (dis)satisfaction. Both of these theories are based on the self-concept of individuals. Individuals' selfconcepts cause them to affiliate with groups of people whom they perceive to be the same as them, or whom they perceive to have the same self-concept as they have of themselves (Turner, 1985: 101).

Social identity theory departs from the premise that individuals strive to achieve a satisfactory concept or image of themselves within a societal setting (Tajfel, 1981:254). In other words, people who have a certain self-concept prefer to associate with others who they believe to have the same self-concept. Similarity-attraction theory is based on the premise that the need for a positive self-identity causes individuals to have preference for, and evaluate more positively, those similar to themselves on the social category on which they base their identity (Strauss, Murray \& Connerly, 2001). Indeed, both Pelled (1996) and Jehn, Northcraft and Neale (1999) found that the higher the diversity in working groups, the greater the intra-group conflict and the lower the group productivity are.

Similarity among group members often influences the extent of inter-personal attraction and as a result also the extent of social integration and the cohesion within a group. In an organisational context, Schneider (1987) has even suggested that over time, organisations evolve (through the processes of attraction, selection and attrition) to a state of 'interpersonal homogeneity'.

Sales management researchers, on the other hand, have investigated whether salespeople are more likely to sell to those who are similar to themselves and whether buyers are more likely to buy from sellers who are similar to themselves (Dwyer, Orlando \& Shepherd, 1998). In other words, are consumers more likely to rate those who are similar to themselves in terms of physical features (gender, cultural group, ethnic group) more favourably than others, and are they therefore more likely to buy from them?

In other words, in a situation of free choice, individuals are attracted to and associate with others similar to themselves. In a sales context, similarity theory would thus predict that salespeople are more likely to see people similar to themselves as potential buyers of their product or service, and also that similarity in the buyer-seller dyad will lead to higher levels of sales effectiveness/performance - a contention both Smith (1998) and in a services marketing setting, Crosby, Evans and Cowles (1990) have found broad empirical support for.

Based on similarity theory we thus postulate that in a service encounter dyad, and particularly a service recovery service encounter dyad, similarity between the service provider on the one hand and the complaining customer on the other hand will positively influence post-recovery customer satisfaction.

For the purposes of this study we selected three situational variables (independent variables) that the literature suggests may impact on satisfaction with service recovery, namely gender (Comer \& Jolson, 1991; Baugher, Varanelli \& Weisbord, 2000), race (Churchill, Collins \& Strang, 1975) and neatness (Bitner, 1992).

\section{The problem statement}

Based on social identity and similarity-attraction theories, an important question is: Do customers experience greater levels of service satisfaction from service providers who are similar to themselves? More specifically: Are consumers more likely to positively evaluate a service recovery effort performed by service providers who are similar to themselves? The triangulation of services marketing and sociological theories thus provides the basis for this study.

The level of customer satisfaction following a service encounter depends on both physical and non-physical cues (Cowell, 1989: 234). Besides the environment in which service encounters take place, the service provider him/herself is an important predictor of customer service satisfaction and any resulting service relationship. The service provider is also often the only contact point that customers have with a service firm (Crosby, Evans \& Cowles, 1990). Service providers are largely responsible for the service satisfaction experienced by customers. The same applies to a situation of poor service delivery, where the service firm tries to recover and, in effect, tries to reestablish customer satisfaction. 
Furthermore, following a service failure and recovery encounter, customers tend to be more emotionally involved and place greater importance on the performance of the service provider performing the service recovery (Smith, Bolton \& Wagner, 1999). In such cases the performance of the service provider is an important predictor of customer service satisfaction.

Social identity and similarity-attraction theories postulate that individuals tend to be biased towards their in-groups and tend to prefer associating with others who are similar to themselves (Turner, 1985:101). Should these theories hold in a services marketing context, then customers would be more satisfied by the service provided to them by a person who is a part of their in-group and who is similar to themselves.

For the purpose of this study, three visible service provider attributes were used and manipulated to investigate their relationships with customer service satisfaction following a service failure and recovery encounter. These service provider attributes are gender, race and neatness (tidiness versus untidiness).

The problem investigated in this study was whether customers are more likely to be satisfied by a service recovery effort that is provided to them by a service provider who is similar to themselves in terms of gender, race and neatness.

\section{Research objective}

This study is based on social identity and similarityattraction theories which, in the context of services marketing, postulate that customers are more likely to be satisfied by service provided to them by service providers who are similar to themselves.

A study conducted by Churchill, Collins and Strang (1975) investigated whether or not salespersons should be similar to their customers in order to increase sales performance. The study matched salespersons and customers on the basis of education, age, height, nationality, race and gender. The empirical results did not offer support for the primary contention of similarity theory. Besides the research conducted by Churchill et al. (1975), which was set in a sales environment, no other study has addressed customer and service provider similarities in a services context.

The objective of this study is to investigate the effect that customer and service provider similarities have on customer service satisfaction following a service failure and recovery encounter. The customer/service provider similarities focused on in this study are gender, race and neatness. These three individual service provider characteristics are thus the independent variables in this study.

\section{The operationalisation of variables}

'Gender' denotes the social and cultural distinctions that humans make between males and females (Turner, 1978: 198). 'Race' can be defined as the superficial differences in people's physical appearance which may include differences in skin colour, hair colour and texture, and facial configurations (Turner, 1985: 236). For the purpose of this study, the independent variable of race considers only black and white demographics. To be 'neat' is defined as carefully done or arranged in order (Hornby, 2000: 783). For the purpose of this study, neatness varies between tidiness and untidiness. The definition of untidy is: 'not neat or well arranged and in a state of disorder' (Hornby, 2000: 1315).

The neatness of the travel agents used as the service providers in this study was changed from tidy to untidy through the crumpling of clothes, undoing of buttons and neck-ties, and the change of hair arrangements.

The dependent variable in this study was customer service satisfaction following a service failure and recovery encounter. For the purpose of this experimental study the service providers were travel agents, and the service failure was the incorrect charging of penalties (cancellation fees) by the travel agent.

\section{Research hypotheses}

The null hypotheses tested in this study were:

$\mathrm{HO}^{1}$ : The gender of the service provider does not influence customer service satisfaction in a service failure and recovery encounter

$\mathrm{HO}^{2}$ : The race of the service provider does not influence customer service satisfaction in a service failure and recovery encounter

$\mathrm{HO}^{3}$ : The physical appearance (neatness) of the service provider does not influence customer service satisfaction in a service failure and recovery encounter

$\mathrm{HO}^{4}$ : The interaction between the gender and race of the service provider does not influence customer service satisfaction in service failure and recovery encounter

$\mathrm{HO}^{5}$ : The interaction between the gender and neatness of the service provider does not influence customer service satisfaction in a service failure and recovery encounter

$\mathrm{HO}^{6}$ : The interaction between the race and neatness of the service provider does not influence customer service satisfaction in a service failure and recovery encounter

$\mathrm{HO}^{7}$ : The interaction between the gender, race and neatness of the service provider does not influence customer service satisfaction in a service failure and recovery encounter 


\section{Research design and methodology}

A quota-based convenience sample of 94 respondents was drawn for the purposes of this study.

The experimental nature of the study allowed the researcher to collect data in an artificial setting and to manipulate the independent variables of service provider gender, race and neatness in order to investigate their relationships with customer service satisfaction following a service failure and recovery. A role-playing method, as previously used by Bitner (1990), Boshoff (2002) and Fischer Gainer and Bristor (1997), was used to collect the data.

A video consisting of eight different scenarios was used in this role-playing exercise. Each video showed a travel agent dealing with a customer in a service failure and recovery encounter. The customer was not visible in the scenarios and their words were scrolled across the bottom of the screen. By keeping the appearance of the complaining customer and his/her tone of voice constant (controlling for appearance and tone of voice) it was possible to enhance the internal validity of the research findings. In each scenario, the gender, race and neatness of the service providers were manipulated. This study thus used a 2 X 2 X 2 withinsubject factorial design. The resultant eight scenarios were:

Scenario 1: A white male, tidy travel agent (WMT)

Scenario 2: A white male, untidy travel agent (WMU)

Scenario 3: A white female, tidy travel agent (WFT)

Scenario 4: A white female, untidy travel agent (WFU)

Scenario 5: A black male, tidy travel agent (BMT)

Scenario 6: A black male, untidy travel agent (BMU)

Scenario 7: A black female, tidy travel agent (BFT)

Scenario 8: A black female, untidy travel agent (BFU)

Respondents were assembled in small groups, provided with questionnaires, and shown the video. Following each scenario, respondents were required to rate their satisfaction with the service provider if they were to be the fictional customer in the scenario, by completing three Likert-type rating scales. This rating was performed for each of the eight video scenarios. The items used to measure neatness and service recovery satisfaction were all linked to a fivepoint Likert-type scale.

Neatness was measured with the following items:

- I like to dress smartly

- When in a working environment, I personally like to look professional

- When I deal with service providers such as bank tellers I expect them to be dressed as professionals

- The appearance of salespeople is important to me

Satisfaction with service recovery was measured with the following items:

- In my opinion, the travel agent provided a satisfactory resolution to the customer's problem on this particular occasion

- Regarding this particular problem, I would be satisfied with the performance of the travel agent
- If I were the customer I would use the same travel agent again in the future

A pre-test was done to assess the effectiveness of the manipulations used. All fourteen respondents who participated described the travel agents correctly in terms of gender and race whilst the three tidy scenarios were rated significantly ( $p<0.001$ ) lower (mean score 2.2 on a sevenpoint scale) than the three tidy scenarios (mean score 4.7 ) in terms of neatness.

\section{Empirical results}

Data were collected over a period of 45 days. A total of 94 completed questionnaires were collected and analysed. The gender, race, age and level of education of the realised sample are outlined in Table 1 below.

Table 1: Demographics of the sample

\begin{tabular}{l|c|c|c}
\hline & White & Black & Total \\
\hline Male & 20 & 29 & $\mathbf{4 9}(52 \%)$ \\
\hline Female & 20 & 25 & $\mathbf{4 5}(48 \%)$ \\
\hline Total & $\mathbf{4 0}(43 \%)$ & $\mathbf{5 4}(57 \%)$ & $\mathbf{9 4}$ \\
\hline
\end{tabular}

\begin{tabular}{l|c|c}
\hline Age & Frequency & Percent \\
\hline $18-25$ years & 30 & 31,9 \\
$26-39$ years & 47 & 50,0 \\
$40-64$ years & 17 & 18,1 \\
Total & $\mathbf{9 4}$ & $\mathbf{1 0 0}$ \\
\hline Level of Education & Frequency & Percent \\
\hline Some High School Completed & 2 & 2,1 \\
High School Completed & 23 & 24,5 \\
Technikon Diploma/Certificate & 12 & 12,8 \\
First University Degree & 33 & 35,1 \\
Honours Degree & 11 & 11,7 \\
Masters Degree & 8 & 8,5 \\
Doctorate & 5 & 5,3 \\
Total & $\mathbf{9 4}$ & $\mathbf{1 0 0}$ \\
\hline
\end{tabular}

\section{The main effects}

The initial analyses that were conducted with the data set were one-way ANOVA tests. A test was performed for each of the three independent variables, namely the service provider's gender, race and neatness (tidiness versus untidiness). The dependent variable in each case was customer service satisfaction with service recovery following a service failure.

\section{Gender}

Table 2 shows that the independent variable Gender had no effect on satisfaction with service recovery following a service failure and recovery $(\mathrm{p}>0.05)$. Therefore, the null hypothesis $\mathrm{HO}^{1}$ was accepted. 
Table 2: ANOVA results: Main effect: gender

\begin{tabular}{|c|c|c|c|c|c|}
\hline & \begin{tabular}{|l|} 
Sum of \\
squares
\end{tabular} & df & $\begin{array}{c}\text { Mean } \\
\text { square }\end{array}$ & $\mathbf{F}$ & $\begin{array}{c}\text { p- } \\
\text { values }\end{array}$ \\
\hline $\begin{array}{l}\text { WMT: } \\
\text { Between } \\
\text { Groups }\end{array}$ & ,001 & 1 & ,001 & ,001 & ,974 \\
\hline $\begin{array}{l}\text { Within } \\
\text { Groups } \\
\text { Total }\end{array}$ & $\begin{array}{l}54,602 \\
54,603\end{array}$ & 93 & ,593 & & \\
\hline $\begin{array}{l}\text { WMU: } \\
\text { Between } \\
\text { Groups }\end{array}$ & ,007 & 1 & ,007 & ,005 & ,944 \\
\hline $\begin{array}{l}\text { Within } \\
\text { Groups } \\
\text { Total }\end{array}$ & $\begin{array}{l}127,148 \\
127,155\end{array}$ & $\begin{array}{l}92 \\
93\end{array}$ & 1,382 & & \\
\hline $\begin{array}{l}\text { WFT: } \\
\text { Between } \\
\text { Groups }\end{array}$ & ,627 & 1 & ,627 & ,733 & ,394 \\
\hline $\begin{array}{l}\text { Within } \\
\text { Groups } \\
\text { Total }\end{array}$ & $\begin{array}{l}78,698 \\
79,325\end{array}$ & $\begin{array}{l}92 \\
93\end{array}$ & ,855 & & \\
\hline $\begin{array}{l}\text { WFU: } \\
\text { Between } \\
\text { Groups }\end{array}$ & ,759 & 1 & ,759 & ,649 & ,423 \\
\hline $\begin{array}{l}\text { Within } \\
\text { Groups } \\
\text { Total }\end{array}$ & $\begin{array}{l}107,674 \\
108,433\end{array}$ & $\begin{array}{l}92 \\
93\end{array}$ & 1,170 & & \\
\hline $\begin{array}{l}\text { BMT: } \\
\text { Between } \\
\text { Groups }\end{array}$ & ,198 & 1 & ,198 & ,231 & ,632 \\
\hline $\begin{array}{l}\text { Within } \\
\text { Groups } \\
\text { Total }\end{array}$ & $\begin{array}{l}78,888 \\
79,086\end{array}$ & $\begin{array}{l}92 \\
93\end{array}$ & ,857 & & \\
\hline $\begin{array}{l}\text { BMU: } \\
\text { Between } \\
\text { Groups }\end{array}$ & ,394 & 1 & ,394 & ,322 & ,572 \\
\hline $\begin{array}{l}\text { Within } \\
\text { Groups } \\
\text { Total }\end{array}$ & $\begin{array}{l}112,356 \\
112,749\end{array}$ & $\begin{array}{l}92 \\
93\end{array}$ & 1,221 & & \\
\hline $\begin{array}{l}\text { BFT: } \\
\text { Between } \\
\text { Groups }\end{array}$ & 1,533 & 1 & 1,533 & 1,941 & 167 \\
\hline $\begin{array}{l}\text { Within } \\
\text { Groups } \\
\text { Total }\end{array}$ & $\begin{array}{l}72,658 \\
74,190\end{array}$ & $\begin{array}{l}92 \\
93\end{array}$ & ,790 & & \\
\hline $\begin{array}{l}\text { BFU: } \\
\text { Between } \\
\text { Groups }\end{array}$ & ,076 & 1 & ,076 & ,060 & ,807 \\
\hline $\begin{array}{l}\text { Within } \\
\text { Groups } \\
\text { Total }\end{array}$ & $\begin{array}{l}116,104 \\
116,180\end{array}$ & $\begin{array}{l}92 \\
93\end{array}$ & 1,262 & & \\
\hline
\end{tabular}

$*=\mathrm{p}<0,05$

WMT $=$ White, male, tidy; WMU = White, male, untidy; WFT =

White, female, tidy: WFU = White, female, untidy; BMT = Black, male, tidy; BMU = Black, male, untidy; BFT = Black, female, tidy; $\mathrm{BFU}=$ Black, female, untidy.

\section{Race}

Table 3 shows that the independent variable Race impacted on satisfaction with service recovery only in the case of the untidy white female (WFU) service provider $(\mathrm{p}<0.05)$. In other words, the two race groups did not evaluate their satisfaction with service recovery the same when the service provider was an untidy white female (WFU).

The significant ANOVA result highlighted in Table 3 was followed up with the Scheffé's post-hoc test. The Sheffé test showed that white respondents rated their satisfaction with service recovery significantly higher (3.48) than blacks (2.91) when an untidy white female (WFU) attempted to recover a service failure.

These results indicate that the null hypothesis $\mathrm{HO}^{2}$ could be accepted with the exception of the case of the untidy white female service provider (WFU). It can be concluded that largely the race of the service provider did not influence customer satisfaction in a service failure and recovery situation.

\section{Neatness}

Table 4 shows that the neatness of service providers on its own did not prove to be an independent variable which significantly affected the dependent variable of satisfaction with service recovery following a service failure $(p>0.05)$. Thus, the null hypothesis $\mathrm{HO}^{3}$ was accepted.

\section{Two-way interaction effects}

Following the assessment of the main effects, ANOVA tests were conducted to investigate possible two-way interactions among the independent variables.

\section{Gender and race}

The gender and race of the service provider were found to have a significant effect $(p<0.05)$ on service recovery satisfaction following a service failure only in the case of the untidy white female (WFU) service provider (Table 5).

The reported difference (Table 5) was again followed up with the post-hoc Sheffé test. This test showed that both black males and black females rated the untidy white female service provider significantly $(p<0.05$ ) lower than both white males and white females (see Table 6).

Based on these results the null hypothesis $\mathrm{HO}^{4}$ can thus be partially accepted. It could be concluded that the combination of the gender and race of the service provider did not generally influence satisfaction with service recovery following a service failure, with the exception of the case of the untidy white female service provider.

\section{Gender and neatness}

Table 7 shows that the two-way interaction between the gender and the neatness of the service provider did not have a significant effect on service satisfaction following a service failure and recovery ( $p>0.05$ ). Therefore, null hypothesis $\mathrm{HO}^{5}$ was accepted. 
Table 3: ANOVA results: Main effect: race

\begin{tabular}{|c|c|c|c|c|c|}
\hline & $\begin{array}{c}\text { Sum of } \\
\text { squares }\end{array}$ & df & $\begin{array}{c}\text { Mean } \\
\text { square }\end{array}$ & $\mathbf{F}$ & $\begin{array}{c}\text { p- } \\
\text { values }\end{array}$ \\
\hline $\begin{array}{l}\text { WMT: } \\
\text { Between } \\
\text { Groups }\end{array}$ &, 523 & 1 & ,523 & ,889 & ,348 \\
\hline $\begin{array}{l}\text { Within } \\
\text { Groups }\end{array}$ & 54,080 & 92 & ,588 & & \\
\hline Total & 54,603 & 93 & & & \\
\hline $\begin{array}{l}\text { WMU: } \\
\text { Between } \\
\text { Groups }\end{array}$ & ,568 & 1 & ,568 & ,413 & ,522 \\
\hline $\begin{array}{l}\text { Within } \\
\text { Groups }\end{array}$ & 126,586 & 92 & 1,376 & & \\
\hline Total & 127,155 & 93 & & & \\
\hline $\begin{array}{l}\text { WFT: } \\
\text { Between } \\
\text { Groups }\end{array}$ & 2,738 & 1 & 2,738 & 3,289 & ,073 \\
\hline $\begin{array}{l}\text { Within } \\
\text { Groups }\end{array}$ & 76,587 & 92 & ,832 & & \\
\hline Total & 79,325 & 93 & & & \\
\hline $\begin{array}{l}\text { WFU: } \\
\text { Between } \\
\text { Groups }\end{array}$ & 7,254 & 1 & 7,254 & 6,596 & ,012* \\
\hline Within & 101,179 & 92 & 1,100 & & \\
\hline Total & 108,433 & 93 & & & \\
\hline $\begin{array}{l}\text { BMT: } \\
\text { Between } \\
\text { Groups }\end{array}$ & ,838 & 1 & ,838 & ,985 & ,324 \\
\hline $\begin{array}{l}\text { Within } \\
\text { Groups }\end{array}$ & 78,248 & 92 & ,851 & & \\
\hline Total & 79,086 & 93 & & & \\
\hline $\begin{array}{l}\text { BMU: } \\
\text { Between } \\
\text { Groups }\end{array}$ & 3,248 & 1 & 3,248 & 2,729 & 102 \\
\hline $\begin{array}{l}\text { Within } \\
\text { Groups }\end{array}$ & 109,501 & 92 & 1,190 & & \\
\hline Total & 112,749 & 93 & & & \\
\hline $\begin{array}{l}\text { BFT: } \\
\text { Between } \\
\text { Groups }\end{array}$ & 1,150 & 1 & 1,150 & 1,449 & ,232 \\
\hline $\begin{array}{l}\text { Within } \\
\text { Groups }\end{array}$ & 73,040 & 92 & ,794 & & \\
\hline Total & 74,190 & 93 & & & \\
\hline $\begin{array}{l}\text { BFU: } \\
\text { Between } \\
\text { Groups }\end{array}$ & 1,758 & 1 & 1,758 & 1,414 & ,237 \\
\hline $\begin{array}{l}\text { Within } \\
\text { Groups }\end{array}$ & 114,421 & 92 & 1,244 & & \\
\hline Total & 116,180 & 93 & & & \\
\hline
\end{tabular}

$*=\mathrm{p}<0,05$

$\mathrm{WMT}=$ White, male, tidy; $\mathrm{WMU}=$ White, male, untidy; $\mathrm{WFT}=$

White, female, tidy: WFU = White, female, untidy; BMT = Black,

male, tidy; BMU = Black, male, untidy; BFT = Black, female, tidy;

$\mathrm{BFU}=$ Black, female, untidy.
Table 4: ANOVA results: Main effect: neatness

\begin{tabular}{|c|c|c|c|c|c|}
\hline & $\begin{array}{c}\text { Sum of } \\
\text { squares }\end{array}$ & df & $\begin{array}{c}\text { Mean } \\
\text { square }\end{array}$ & $\mathbf{F}$ & $\begin{array}{c}\text { p- } \\
\text { values }\end{array}$ \\
\hline $\begin{array}{l}\text { WMT: } \\
\text { Between } \\
\text { Groups }\end{array}$ & ,005 & 1 & ,005 & ,008 & ,928 \\
\hline $\begin{array}{l}\text { Within } \\
\text { Groups }\end{array}$ & 54,598 & 92 & ,593 & & \\
\hline Total & 54,603 & 93 & & & \\
\hline $\begin{array}{l}\text { WMU: } \\
\text { Between } \\
\text { Groups }\end{array}$ & 3,454 & 1 & 3,454 & 2,569 & ,112 \\
\hline $\begin{array}{l}\text { Within } \\
\text { Groups }\end{array}$ & 123,700 & 92 & 1,345 & & \\
\hline Total & 127,155 & 93 & & & \\
\hline $\begin{array}{l}\text { WFT: } \\
\text { Between } \\
\text { Groups }\end{array}$ & 169 & 1 & ,169 & ,197 & ,658 \\
\hline $\begin{array}{l}\text { Within } \\
\text { Groups }\end{array}$ & 79,155 & 92 & ,860 & & \\
\hline Total & 79,325 & 93 & & & \\
\hline $\begin{array}{l}\text { WFU: } \\
\text { Between } \\
\text { Groups }\end{array}$ & 2,000 & 1 & 2,000 & 1,728 & ,192 \\
\hline $\begin{array}{l}\text { Within } \\
\text { Groups }\end{array}$ & 106,434 & 92 & 1,157 & & \\
\hline Total & 108,433 & 93 & & & \\
\hline $\begin{array}{l}\text { BMT: } \\
\text { Between } \\
\text { Groups }\end{array}$ & ,523 & 1 & ,523 & ,612 & ,436 \\
\hline $\begin{array}{l}\text { Within } \\
\text { Groups }\end{array}$ & 78,563 & 92 & ,854 & & \\
\hline Total & 79,086 & 93 & & & \\
\hline $\begin{array}{l}\text { BMU: } \\
\text { Between } \\
\text { Groups }\end{array}$ & 3,206 & 1 & 3,206 & 2,693 & ,104 \\
\hline $\begin{array}{l}\text { Within } \\
\text { Groups }\end{array}$ & 109,543 & 92 & 1,191 & & \\
\hline Total & 112,749 & 93 & & & \\
\hline $\begin{array}{l}\text { BFT: } \\
\text { Between } \\
\text { Groups }\end{array}$ & 231 & 1 & ,231 & ,287 & ,593 \\
\hline $\begin{array}{l}\text { Within } \\
\text { Groups }\end{array}$ & 73,959 & 92 & ,804 & & \\
\hline Total & 74,190 & 93 & & & \\
\hline $\begin{array}{l}\text { BFU: } \\
\text { Between } \\
\text { Groups }\end{array}$ & 1,022 & 1 & 1,022 & ,816 & ,369 \\
\hline $\begin{array}{l}\text { Within } \\
\text { Groups }\end{array}$ & 115,158 & 92 & 1,252 & & \\
\hline Total & 116,180 & 93 & & & \\
\hline
\end{tabular}

$*=\mathrm{p}<0,05$

WMT = White, male, tidy; WMU = White, male, untidy; WFT = White, female, tidy: WFU = White, female, untidy; BMT = Black, male, tidy; BMU = Black, male, untidy; BFT = Black, female, tidy; BFU = Black, female, untidy. 
Table 5: ANOVA results: Two-way interactions between gender and race

\begin{tabular}{|c|c|c|c|c|c|}
\hline & $\begin{array}{l}\text { Sum of } \\
\text { squares }\end{array}$ & df & $\begin{array}{l}\text { Mean } \\
\text { square }\end{array}$ & $\mathbf{F}$ & $\begin{array}{c}\text { p- } \\
\text { values }\end{array}$ \\
\hline $\begin{array}{l}\text { WMT: } \\
\text { Between } \\
\text { Groups }\end{array}$ & ,558 & 3 & ,186 & ,310 & 818 \\
\hline $\begin{array}{l}\text { Within } \\
\text { Groups }\end{array}$ & 54,045 & 90 & ,600 & & \\
\hline Total & 54,603 & 93 & & & \\
\hline $\begin{array}{l}\text { WMU: } \\
\text { Between } \\
\text { Groups }\end{array}$ & ,581 & 3 & ,194 & ,138 & ,937 \\
\hline $\begin{array}{l}\text { Within } \\
\text { Groups }\end{array}$ & 126,573 & 90 & 1,406 & & \\
\hline Total & 127,155 & 93 & & & \\
\hline $\begin{array}{l}\text { WFT: } \\
\text { Between } \\
\text { Groups }\end{array}$ & 3,467 & 3 & 1,156 & 1,371 & ,257 \\
\hline $\begin{array}{l}\text { Within } \\
\text { Groups }\end{array}$ & 75,858 & 90 & ,843 & & \\
\hline Total & 79,325 & 93 & & & \\
\hline $\begin{array}{l}\text { WFU: } \\
\text { Between } \\
\text { Groups }\end{array}$ & 10,339 & 3 & 3,446 & 3,162 & ,028* \\
\hline $\begin{array}{l}\text { Within } \\
\text { Groups }\end{array}$ & 98,094 & 90 & 1,090 & & \\
\hline Total & 108,433 & 93 & & & \\
\hline $\begin{array}{l}\text { BMT: } \\
\text { Between } \\
\text { Groups }\end{array}$ & 1,150 & 3 & ,383 & ,443 & ,723 \\
\hline $\begin{array}{l}\text { Within } \\
\text { Groups }\end{array}$ & 77,936 & 90 & ,866 & & \\
\hline Total & 79,086 & 93 & & & \\
\hline $\begin{array}{l}\text { BMU: } \\
\text { Between } \\
\text { Groups }\end{array}$ & 3,608 & 3 & 1,203 & 992 & ,400 \\
\hline $\begin{array}{l}\text { Within } \\
\text { Groups }\end{array}$ & 109,141 & 90 & 1,213 & & \\
\hline Total & 112,749 & 93 & & & \\
\hline $\begin{array}{l}\text { BFT: } \\
\text { Between } \\
\text { Groups }\end{array}$ & 2,756 & 3 & ,919 & 1,157 & ,331 \\
\hline $\begin{array}{l}\text { Within } \\
\text { Groups }\end{array}$ & 71,434 & 90 & ,794 & & \\
\hline Total & 74,190 & 93 & & & \\
\hline $\begin{array}{l}\text { BFU: } \\
\text { Between } \\
\text { Groups }\end{array}$ & 2,108 & 3 & ,703 & ,555 & ,646 \\
\hline $\begin{array}{l}\text { Within } \\
\text { Groups }\end{array}$ & 114,071 & 90 & 1,267 & & \\
\hline Total & 116,180 & 93 & & & \\
\hline
\end{tabular}

$*=\mathrm{p}<0,05$

WMT $=$ White, male, tidy; WMU = White, male, untidy; WFT =

White, female, tidy: WFU = White, female, untidy; BMT = Black, male, tidy; BMU = Black, male, untidy; BFT = Black, female, tidy; $\mathrm{BFU}=$ Black, female, untidy.
Table 6: Results of Scheffé test

\begin{tabular}{l|c|c}
\hline Race-Gender interaction & n & $\begin{array}{c}\text { Mean score } \\
\text { (five-point scale) }\end{array}$ \\
\hline Black male sub-sample & 29 & 2,89 \\
Black female sub-sample & 25 & 2,95 \\
White female sub-sample & 20 & 3,20 \\
White male sub-sample & 20 & 3,75 \\
\hline
\end{tabular}

\section{Race and neatness}

Table 8 shows that the two-way interaction between the race and the neatness of the service provider did not significantly $(p>0,05)$ impact on satisfaction with service recovery following a service failure. The null hypothesis $\mathrm{HO}^{6}$ was therefore accepted.

\section{Three-way interaction effects}

Following the main effects and two-way interaction analyses a further ANOVA analysis was conducted to investigate the combined effect of all three independent variables on the dependent variable (satisfaction with service recovery). This test was conducted at a 0.05 confidence level.

\section{Gender, race and neatness}

As Table 9 shows, when all three independent variables (gender, race and neatness) were analysed (three-way interaction effect) no significant influence was found on the dependent variable satisfaction with service recovery. Therefore, the null hypothesis $\mathrm{HO}^{7}$ was accepted.

\section{Conclusion}

The reported empirical results have shown that, apart from a few minor exceptions, the proposed null hypotheses could not be rejected. The implication is that, unlike what social identity theory and similarity theory would predict, the similarity of physical features of human beings such as their gender, their skin pigmentation, and their appearance in terms of neatness do not influence their assessment of how satisfied they are with a service provider's service recovery efforts.

\section{Internal and external validity}

In any experimental study both internal validity and external validity are major concerns. Every effort was made to enhance both types of validity in this study. A role-playing approach was used to collect the data, as in many other similar studies, as they are more realistic than other data collection techniques (pen-and-pencil type tests, for instance).

In short, very realistic service failure (over-charging of cancellation fees) and recovery (apologies; we made a mistake; cancellation fees only a fraction of what thought to be) manipulations were used. Because they closely resemble real-life situations this approach enhances the external validity of the findings. 
Table 7: ANOVA results: Two-way interactions between gender and neatness

\begin{tabular}{|c|c|c|c|c|c|}
\hline & $\begin{array}{c}\text { Sum of } \\
\text { squares }\end{array}$ & df & $\begin{array}{l}\text { Mean } \\
\text { square }\end{array}$ & $\mathbf{F}$ & $\begin{array}{c}\text { p- } \\
\text { values }\end{array}$ \\
\hline $\begin{array}{l}\text { WMT: } \\
\text { Between } \\
\text { Groups }\end{array}$ & ,235 & 3 & ,078 & ,130 & ,942 \\
\hline $\begin{array}{l}\text { Within } \\
\text { Groups }\end{array}$ & 54,368 & 90 & ,604 & & \\
\hline Total & 54,603 & 93 & & & \\
\hline $\begin{array}{l}\text { WMU: } \\
\text { Between } \\
\text { Groups }\end{array}$ & 4,618 & 3 & 1,539 & 1,131 & ,341 \\
\hline $\begin{array}{l}\text { Within } \\
\text { Groups }\end{array}$ & & 90 & 1,362 & & \\
\hline Total & 127,155 & 93 & & & \\
\hline $\begin{array}{l}\text { WFT: } \\
\text { Between } \\
\text { Groups }\end{array}$ & 1,336 & 3 & ,445 & ,514 & ,674 \\
\hline $\begin{array}{l}\text { Within } \\
\text { Groups }\end{array}$ & 77,989 & 90 & ,867 & & \\
\hline Total & 79,325 & 93 & & & \\
\hline $\begin{array}{l}\text { WFU: } \\
\text { Between } \\
\text { Groups }\end{array}$ & 3,597 & 3 & 1,199 & 1,029 & ,383 \\
\hline $\begin{array}{l}\text { Within } \\
\text { Groups }\end{array}$ & 104,836 & 90 & 1,165 & & \\
\hline Total & 108,433 & 93 & & & \\
\hline $\begin{array}{l}\text { BMT: } \\
\text { Between } \\
\text { Groups }\end{array}$ & 2,880 & 3 & ,960 & 1,134 & ,340 \\
\hline $\begin{array}{l}\text { Within } \\
\text { Groups }\end{array}$ & 76,206 & 90 & ,847 & & \\
\hline Total & 79,086 & 93 & & & \\
\hline $\begin{array}{l}\text { BMU: } \\
\text { Between } \\
\text { Groups }\end{array}$ & 3,762 & 3 & 1,254 & 1,036 & ,381 \\
\hline $\begin{array}{l}\text { Within } \\
\text { Groups }\end{array}$ & 108,987 & 90 & 1,211 & & \\
\hline Total & 112,749 & 93 & & & \\
\hline $\begin{array}{l}\text { BFT: } \\
\text { Between } \\
\text { Groups }\end{array}$ & 1,974 & 3 & ,658 & ,820 & ,486 \\
\hline $\begin{array}{l}\text { Within } \\
\text { Groups }\end{array}$ & 72,217 & 90 & ,802 & & \\
\hline Total & 74,190 & 93 & & & \\
\hline $\begin{array}{l}\text { BFU: } \\
\text { Between } \\
\text { Groups }\end{array}$ & 1,106 & 3 & ,369 & ,288 & ,834 \\
\hline $\begin{array}{l}\text { Within } \\
\text { Groups }\end{array}$ & 115,074 & 90 & 1,279 & & \\
\hline Total & 116,180 & 93 & & & \\
\hline
\end{tabular}

WMT = White, male, tidy; WMU = White, male, untidy; WFT = White, female, tidy: WFU = White, female, untidy; BMT = Black, male, tidy; BMU = Black, male, untidy; BFT = Black, female, tidy; $\mathrm{BFU}=$ Black, female, untidy.
Table 8: ANOVA results: Two-way interactions between race and neatness

\begin{tabular}{|c|c|c|c|c|c|}
\hline & $\begin{array}{c}\text { Sum of } \\
\text { squares }\end{array}$ & df & $\begin{array}{l}\text { Mean } \\
\text { square }\end{array}$ & $\mathbf{F}$ & $\begin{array}{c}\mathbf{p}^{-} \\
\text {values }\end{array}$ \\
\hline $\begin{array}{l}\text { WMT: } \\
\text { Between } \\
\text { Groups }\end{array}$ & ,537 & 3 & 179 & ,298 & ,827 \\
\hline $\begin{array}{l}\text { Within } \\
\text { Groups }\end{array}$ & 54,065 & 90 & ,601 & & \\
\hline Total & 54,603 & 93 & & & \\
\hline $\begin{array}{l}\text { WMU: } \\
\text { Between } \\
\text { Groups }\end{array}$ & 4,294 & 3 & 1,431 & 1,049 & ,375 \\
\hline $\begin{array}{l}\text { Within } \\
\text { Groups }\end{array}$ & & 90 & 1,365 & & \\
\hline Total & 127,155 & 93 & & & \\
\hline $\begin{array}{l}\text { WFT: } \\
\text { Between } \\
\text { Groups }\end{array}$ & 3,349 & 3 & 1,116 & 1,322 & ,272 \\
\hline $\begin{array}{l}\text { Within } \\
\text { Groups }\end{array}$ & 75,976 & 90 & ,844 & & \\
\hline Total & 79,325 & 93 & & & \\
\hline $\begin{array}{l}\text { WFU: } \\
\text { Between } \\
\text { Groups }\end{array}$ & 9,016 & 3 & 3,005 & 2,721 & ,05 \\
\hline $\begin{array}{l}\text { Within } \\
\text { Groups }\end{array}$ & 99,417 & 90 & 1,105 & & \\
\hline Total & 108,433 & 93 & & & \\
\hline $\begin{array}{l}\text { BMT: } \\
\text { Between } \\
\text { Groups }\end{array}$ & 2,522 & 3 & ,841 & 988 & ,402 \\
\hline $\begin{array}{l}\text { Within } \\
\text { Groups }\end{array}$ & 76,564 & 90 & ,851 & & \\
\hline Total & 79,086 & 93 & & & \\
\hline $\begin{array}{l}\text { BMU: } \\
\text { Between } \\
\text { Groups }\end{array}$ & 6,389 & 3 & 2,130 & 1,802 & ,152 \\
\hline $\begin{array}{l}\text { Within } \\
\text { Groups }\end{array}$ & 106,360 & 90 & 1,182 & & \\
\hline Total & 112,749 & 93 & & & \\
\hline $\begin{array}{l}\text { BFT: } \\
\text { Between } \\
\text { Groups }\end{array}$ & 1,360 & 3 & ,453 & ,560 & ,643 \\
\hline $\begin{array}{l}\text { Within } \\
\text { Groups }\end{array}$ & 72,830 & 90 & 809 & & \\
\hline Total & 74,190 & 93 & & & \\
\hline $\begin{array}{l}\text { BFU: } \\
\text { Between } \\
\text { Groups }\end{array}$ & 3,104 & 3 & 1,035 & ,823 & ,484 \\
\hline $\begin{array}{l}\text { Within } \\
\text { Groups }\end{array}$ & 113,076 & 90 & 1,256 & & \\
\hline Total & 116,180 & 93 & & & \\
\hline
\end{tabular}

WMT = White, male, tidy; WMU = White, male, untidy; WFT = White, female, tidy: WFU = White, female, untidy; BMT = Black, male, tidy; BMU = Black, male, untidy; BFT = Black, female, tidy; $\mathrm{BFU}=$ Black, female, untidy. 
Table 9: ANOVA results: Three-way interaction between gender, race and neatness

\begin{tabular}{|c|c|c|c|c|c|}
\hline & $\begin{array}{l}\text { Sum of } \\
\text { squares }\end{array}$ & df & $\begin{array}{c}\text { Mean } \\
\text { square }\end{array}$ & $\mathbf{F}$ & $\begin{array}{c}\text { p- } \\
\text { values }\end{array}$ \\
\hline $\begin{array}{l}\text { WMT: } \\
\text { Between } \\
\text { groups }\end{array}$ & 2,221 & 7 & ,317 & ,521 & ,817 \\
\hline $\begin{array}{l}\text { Within } \\
\text { groups }\end{array}$ & 52,382 & 86 & 609 & & \\
\hline Total & 54,603 & 93 & & & \\
\hline $\begin{array}{l}\text { WMU: } \\
\text { Between } \\
\text { groups }\end{array}$ & 6,138 & 7 & ,877 & 623 & ,735 \\
\hline $\begin{array}{l}\text { Within } \\
\text { groups }\end{array}$ & 121,016 & 86 & 1,407 & & \\
\hline Total & 127,155 & 93 & & & \\
\hline $\begin{array}{l}\text { WFT: } \\
\text { Between } \\
\text { groups }\end{array}$ & 6,093 & 7 & ,870 & 1,022 & ,422 \\
\hline $\begin{array}{l}\text { Within } \\
\text { groups }\end{array}$ & 73,231 & 86 & ,852 & & \\
\hline Total & 79,325 & 93 & & & \\
\hline $\begin{array}{l}\text { WFU: } \\
\text { Between } \\
\text { groups }\end{array}$ & 14,363 & 7 & 2,052 & 1,876 & ,083 \\
\hline $\begin{array}{l}\text { Within } \\
\text { groups }\end{array}$ & 94,071 & 86 & 1,094 & & \\
\hline Total & 108,433 & 93 & & & \\
\hline $\begin{array}{l}\text { BMT: } \\
\text { Between } \\
\text { groups }\end{array}$ & 4,926 & 7 & ,704 & ,816 & ,576 \\
\hline $\begin{array}{l}\text { Within } \\
\text { groups }\end{array}$ & 74,160 & 86 & ,862 & & \\
\hline Total & 79,086 & 93 & & & \\
\hline $\begin{array}{l}\text { BMU: } \\
\text { Between } \\
\text { groups }\end{array}$ & 9,772 & 7 & 1,396 & 1,166 & ,331 \\
\hline $\begin{array}{l}\text { Within } \\
\text { groups }\end{array}$ & 102,977 & 86 & 1,197 & & \\
\hline Total & 112,749 & 93 & & & \\
\hline $\begin{array}{l}\text { BFT: } \\
\text { Between } \\
\text { groups }\end{array}$ & 4,505 & 7 & ,644 & ,794 & ,594 \\
\hline $\begin{array}{l}\text { Within } \\
\text { groups }\end{array}$ & 69,685 & 86 & 810 & & \\
\hline Total & 74,190 & 93 & & & \\
\hline $\begin{array}{l}\text { BFU: } \\
\text { Between } \\
\text { groups }\end{array}$ & 8,384 & 7 & 1,198 & ,956 & ,469 \\
\hline $\begin{array}{l}\text { Within } \\
\text { groups }\end{array}$ & 107,795 & 86 & 1,253 & & \\
\hline Total & 116,180 & 93 & & & \\
\hline
\end{tabular}

WMT = White, male, tidy; WMU = White, male, untidy; WFT = White, female, tidy: WFU = White, female, untidy; BMT = Black, male, tidy; BMU = Black, male, untidy; BFT = Black, female, tidy; BFU = Black, female, untidy.
To ensure the internal validity of the findings the influence of extraneous variables were controlled for. For instance, the appearance and tone of voice of the complaining customer were controlled for by scrolling the words of the complainant across the screen. To control for other environmental influences each scenario was filmed in exactly the same travel agency environment.

\section{Limitation of the study}

Despite the efforts to ensure internal validity, two extraneous variables were difficult to control for. Firstly, because all 94 respondents saw all eight scenarios, it is possible that some learning and maturation may have occurred. In other words, it is possible that some of the respondents may have worked out what the purpose of the study was, and this realisation may have biased their subsequent responses. A second potential limitation is that it was at times difficult to effectively manipulate the appearance of the actors (travel agents). Where the white actors' relatively long hair could be ruffled to create a perception of untidiness, the black actors' relatively short hair could not. In other words, the distinction between an untidy and a tidy/neat service provider may not have been distinct enough for some of the respondents to notice.

\section{Managerial implications}

Despite the potential limitations, the managerial implications emanating from this study are clear. Service managers do not have to concern themselves too much with what their staff responsible for service recovery look like in terms of physical appearance. Instead, it appears that what is done during service recovery (the remedial action) is far more important than who does it and what they look like. Recruitment and training for service recovery thus need to focus more on skills and capabilities rather than what people look like.

\section{References}

Baugher, D., Varanelli, A. \& Weisbord, E. 2000. 'Gender and culture diversity occurring in self-formed work groups', Journal of Managerial Issues, 12(4): 391- 407.

Belk, R.W. 1975. 'Situational variables and consumer behaviour', Journal of Consumer Research, 2(4):157-164.

Bitner, M. J. 1990. 'Evaluating service encounters: The effect of physical surroundings and employee responses', Journal of Marketing, 54(2): 69-82.

Bitner, M. J. 1992. 'Servicescapes: The impact of physical surroundings on customers and employees', Journal of Marketing, 56(1):57-71.

Bitner, M.J., Booms, B.H. \& Tetreault, M.S. 1990. 'The service encounter: Diagnosing favourable and unfavourable incidents', Journal of Marketing, 54(1): 71-84.

Boshoff, C. 2002. 'Service advertising: An exploratory study of risk perceptions', Journal of Service Research, 4(4): 290-292. 
Bougie, R., Pieters, R. \& Zeelenberg, M. 2003. Angry customers don't come back, they get back: The experience and behavioural implications of anger and dissatisfaction in services? Journal of the Academy of Marketing Science, 31(4): 377-393.

Brady, M.K., Cronin, J.J. \& Brand, R.R. 2002. 'Performance-only measurement of service quality: A replication and extension', Journal of Business Research, 55:17-31.

Cho, S. 2001. 'Influence of consumer age and clothing type of salesperson on consumer satisfaction with salesperson's performance'. Unpublished master's dissertation, Virginia Polytechnic Institute and State University, Blacksburg, Virginia, USA.

Churchill, G.A., Collins, R.H. \& Strang, W.A. 1975. 'Should retail salespersons be similar to their customers?' Journal of Retailing, 51(3): 29-42.

Comer, L.B. \& Jolson, M.A. 1991. 'Perceptions of gender stereotypic behaviour: An exploratory study of women in selling', Journal of Personal Selling and Sales Management, 11(1): 43-59.

Cowell, D.W. 1989. The marketing of services. Oxford: Heinemann.

Crosby, A., Evans, K.R. \& Cowles, D. 1990. 'Relationship quality in services selling: An interpersonal influence perspective', Journal of Marketing, 54(3): 68-81.

Dwyer, S., Orlando, R. \& Shepard, C.D. 1998. 'An exploratory study of gender and age matching in the salesperson-prospective customer dyad: Testing similarityperformance predictions', Journal of Personal Selling and Sales Management, 18(4): 55-69.

Engel, J.F., Kollat, D.T. \& Blackwell, R.D. 1969. 'Personality measures and market segmentation', Business Horizons, 12 (June): 61-70.

Evans, K.R., Kleine, R.E., Landry, T.D. \& Crosby, L.A. 2000. 'How first impressions of a customer impact effectiveness in an initial sales encounter', Journal of the Academy of Marketing Science, 28(4): 512-526.

Fischer, E., Gainer, B. \& Bristor, J. 1997. 'The sex of the service provider: Does it influence perceptions of service quality?’ Journal of Retailing, 73(3): 361-382.

Hess, R.L., Ganesan, S. \& Klein, N.M. 2003. 'Service failure and recovery: The impact of relationship factors on customer satisfaction', Journal of the Academy of Marketing Science, 31(2): 127-145.

Hornby, A. S. 2000. Oxford advanced learner's dictionary of current English. (6 $6^{\text {th }}$ Edition). Oxford: Oxford University Press.

Jehn, K.A., Northcraft, G.B. \& Neale, M.A. 1999. 'Why differences make a difference: A field study of diversity, conflict and performance in groups', Administrative Science Quarterly, 44: 741-763.

Parasuraman, A., Zeithaml, V.A. \& Berry, L.L. 1988. 'SERVQUAL: A multiple-item scale for measuring service quality’, Journal of Retailing, 64(1): 1, 12-40.

Pelled, L.H. 1996. 'Relational demography and perceptions of group conflict and performance: A field investigation', The International Journal of Conflict Management, 7(3): 230-246.

Schneider, B. 1987. 'The people make the place'. Personnel Psychology, 40: 437-453.

Smith, J.B. 1998. 'Buyer-seller relationships: Similarity, relationship management and quality', Psychology and Marketing, 15(1): 3-21.

Smith, A.K. \& Bolton, R.N. 2002. 'The effect of customer's emotional responses to service failures and their recovery effort evaluations and satisfaction judgments', Journal of the Academy of Marketing Science, 30(1):5-23.

Smith, A.K., Bolton, R.N. \& Wagner, J. 1999. 'A model of customer satisfaction with service encounters involving failure and recovery', Journal of Marketing Research, 36(3): 356-372.

South Africa. 2003. [online] URL: www.tradeinfo.cec.eu.int/doclib/docs/2003/september.

Strauss, J.P., Murray, R.B. \& Connerly, M.L. 2001. 'An investigation of personality similarity effects on peer and supervisor ratings and the role of familiarity and liking', Journal of Occupational and Organizational Psychology, 74: 637-657.

Tajfel, H. 1981. Human groups and social categories: Studies in social psychology. England: Cambridge University Press.

Turner, J.H. 1978. Sociology: Studying the human system. Santa Monica, California: Goodyear.

Turner, J.H. 1985. Sociology: The science of human organization. Chicago, Illinois: Nelson-Hall Inc.

World Bank, 2006. 'South Africa at a glance'. [online] URL:http://devdata.worldbank.org/AAG/zaf_aag.pdf.

Zeithaml, V.A., Bitner, M.J. \& Gremler, D.D. 2006. Services marketing: Integrating customer focus across the firm. New York: McGraw-Hill. 
Tidy White Male Travel Agent

Tidy Black Female Travel Agent

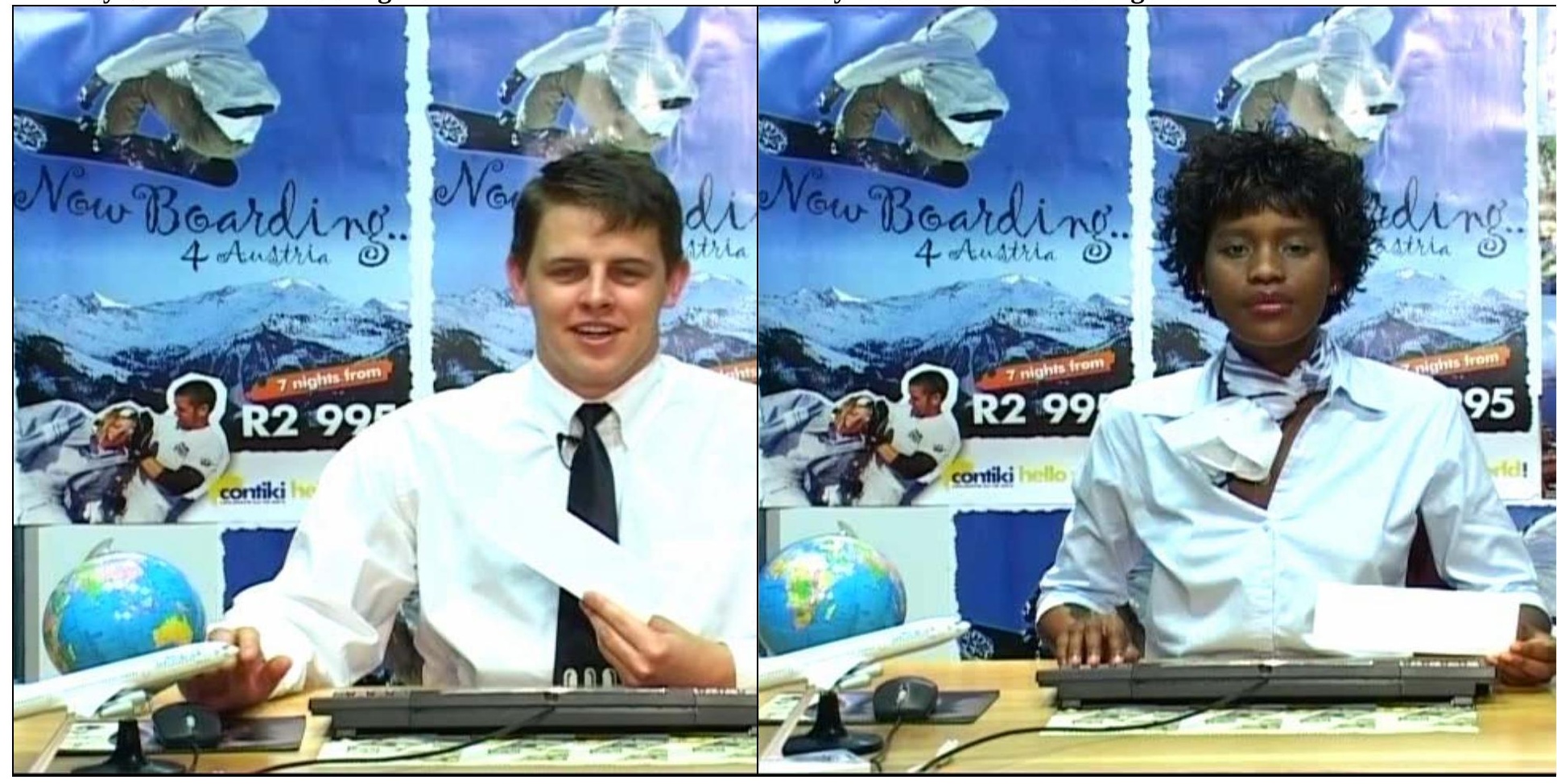

Untidy White Male Travel Agent

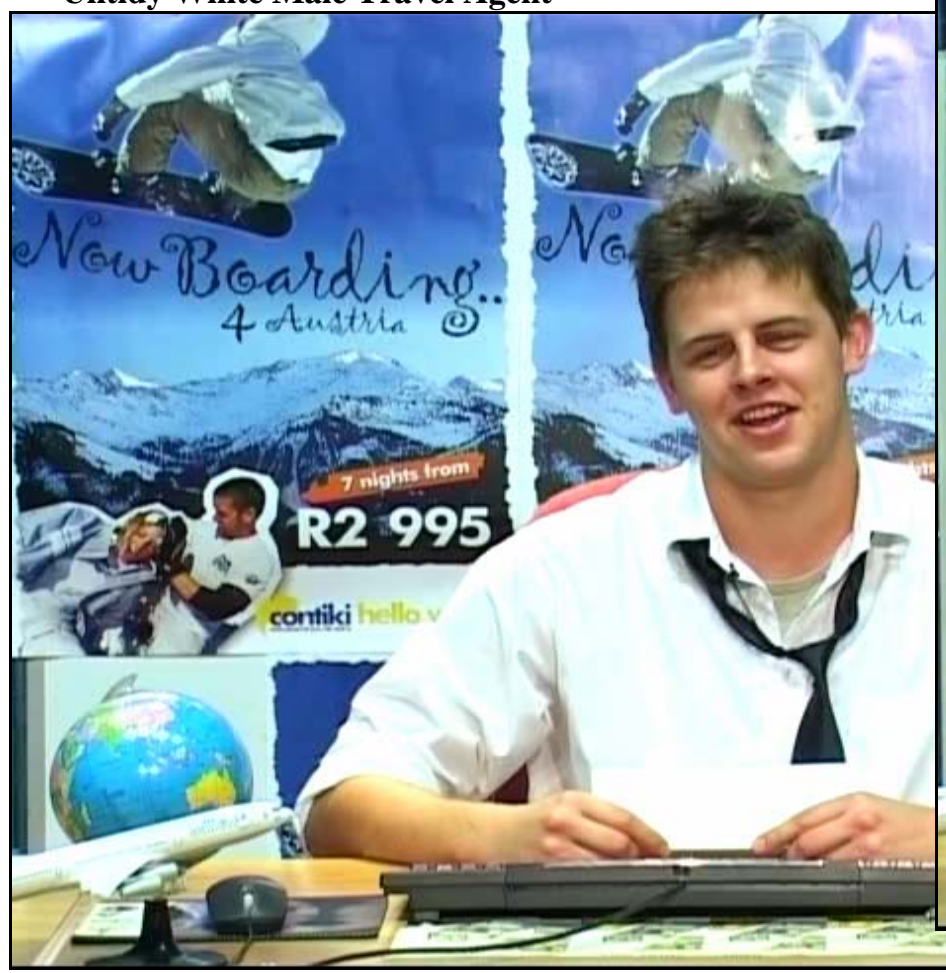

Untidy Black Female Travel Agent

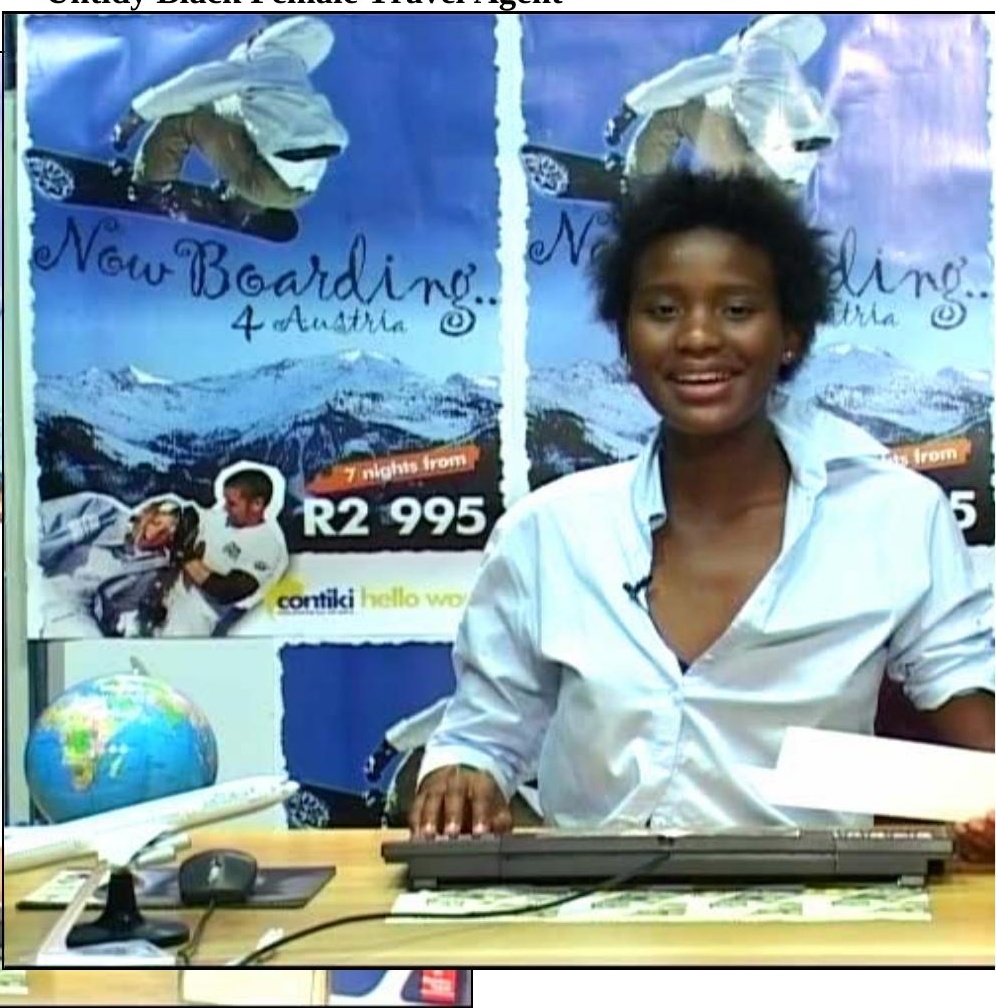

